\title{
International Journal of

\section{THE FORMATION OF KANGKAR AS THE FRONTIER CHINESE SETTLEMENT IN JOHOR, MALAYSIA}

Low Hui Ching ${ }^{\text {a }}$, Raja Nafida Raja Shahminan ${ }^{\text {b* }}$, Gurupiah Mursib ${ }^{\mathrm{c}}$

${ }^{a}$ Department of Architecture, Faculty of Built Environment, Universiti Teknologi Malaysia, 81310 UTM Johor Bahru, Johor, Malaysia

${ }^{\mathrm{b}}$ Center for the Study of Built Environment in the Malay World (KALAM), Faculty of Built Environment, Universiti Teknologi Malaysia, 81310 UTM Johor Bahru, Johor, Malaysia

'Institut Sultan Iskandar, Universiti Teknologi Malaysia, Jalan Sultan Yahya Petra, 54100 Kuala Lumpur, Malaysia
Article history

Received

15 May 2018

Received in revised form

19 December 2018

Accepted

25 December 2018

Published 01 April 2019

*Corresponding author

b-nafida@utm.my

DOI: $10.11113 /$ ijbes.v6.n1-2.382

\begin{abstract}
In the $19^{\text {th }}$ century, Chinese immigrants were drawn to Johor via the entirely unique Kangchu system that was only adapted in the state, later contributed significantly to its economic progress. The Chinese came for pepper and gambier plantation and settled at riverside which formed the frontier Chinese settlement called "Kangkar". It is also believed that kangkar is the earliest established Chinese settlement in Johor, then many of them substituted by New Village in 1950s, and today's modern housing in the $20^{\text {th }}$ century. Irony the kangkar settlements are declining while some already abandoned. Furthermore, study of Chinese settled at Johor in kangkar settlement is still lacking, which severely constrain the preservation of such historical settlement. To help fill this gap, this paper aims to delineate the kangkar settlement which represents strong historical significance to Chinese architectural paradigm in Johor. It is crucial to start paying attention on this Chinese heritage to avoid irreversible loss of humanity's heritage as well as diversity. As the formation of kangkar settlement was mainly ranged from 1844 to 1917, historical data was collected through content analysis of archival documents, literature reviews, and interviews of scholars. The special terms used were revealed such as Kangchu, kangkar, and "surat sungai". Kangkar as a unique Chinese living settlement which existed due to Kangchu system, plays important and positive roles in Johor development in terms of economy, coexistence, and identity. It is hence crucial to preserve the kangkar settlements by providing insight of guideline to sustain and avoid further decline.
\end{abstract}

Keywords: Kangkar, Chinese settlement, Johor, Kangchu

(C) 2019 Penerbit UTM Press. All rights reserved

\section{Introduction}

The unstable and famine in southern China during early $19^{\text {th }}$ century drove many Chinese to leave the country to come over Malaya and Southeast Asia in making fortune. In Johor, the Chinese immigrants were invited by Temenggung Daeng Ibrahim to help in pepper and gambier cultivation through Kangchu system (Coope, 1936; Trocki, 1975). It was estimated only $5 \%$ of the land was developed before Kangchu system (Onn, Wu, \& Su, 2013). Under the implementation of Kangchu system, Johor became the largest gambier producer in the world during 1880 s which marked its significant contribution to Johor economic progress (Jackson, 1968; Pek, 2015). The pepper and gambier plantation eventually 
evolved to rubber estate in the $1900 \mathrm{~s}$, and then pineapple and oil palm estate in 1960s. Till date, Malaysia is the world's second largest palm oil producer after Indonesia while Johor is the top in Peninsular Malaysia (Department of Statisctics, 2017). This marks the importance of Chinese as the frontier to modern Johor economic development.

Johor was the only region adapted Kangchu system, the entirely unique and efficacious system of landtenure as well as co-operative gambier and pepper cultivation. Under this circumstance, a riverine settlement for the Chinese immigrants of pepper and gambier plantation cluster called "Kangkar" was formed (Loh, 2017). There are many places in Johor still inherited name of kangkar, for instance Kangkar Tebrau in Johor Bahru, Kangkar Bahru in Yong Peng, Kangkar Lama in Kota Tinggi, Kangkar Sedi in Batu Pahat (Cowgill, 1924), and the like. It was believed that many places in Johor was explored and started with kangkar settlements.

There are few historical timeline that must be mentioned which led to the decline of kangkar settlements. The Japanese invasion during WorldWar II in 1940s had given great impact to some kangkar settlements. They treated the Chinese particularly harshly because of their support for mainland China against Japanese (Yoji \& Mako, 2008). Then in 1950s, Briggs' plan was established to defeat the Malayan communits. New Village was introduced to resettle the Malayan peasantry in rural area, largely of Chinese descent (Ooi, 2009). Many kangkar settlements at this point were abandoned, the residents shifted to New Villages as instructed. The urbanization and modernization in the 20th century have further aggravated the loss of kangkar settlements. Irony, there are still lack of documentation and proper records mentioned on kangkar settlements. It is crucial to start paying attention on this Chinese heritage to avoid irreversible loss of humanity's heritage as well as diversity. Hence, this paper aims to delineate kangkar settlements which represents strong historical significance to Chinese architectural paradigm in Johor.

\section{Methodology}

Refer to the current study which aims to delineate kangkar as the frontier Chinese settlement in Johor, it is essential to understand the formation of kangkar settlements in Johor. As kangkar settlements were established from 1844 to 1917 where the Kangchu system being introduced, historical method is suggested to discover its formation.

Historical method is a qualitative approach which allows to reconstruct a phenomenon in relation to history (Filho, 2016). It is a type of scientific research work to investigate elements from history. It differs from other scientific researches as the subject matter is hard to capture, that is the past. The formation of kangkar settlements which happened between 1844 to 1917 considered as the past and subject matter that is unable to be captured in today's context especially through field work.

Besides, historical study has also been utilized in the early stages of design process (Wyche, Sengers, \& Grinter, 2006). The study of the past will help to provide insight of guideline (Spilackova, 2012) in sustaining the kangkar settlements and avoid their further decline. The steps to carry out historical method are suggested as follow:

a) Defining the research issue or problem (Spilackova, 2012; Wyche et al., 2006)

As discussed above, it is important to understand the formation of kangkar settlements which act as the frontier of Chinese settlement in Johor, originated between 1844 to 1917 .

b) Collecting information or data from sources Information or data collected are historical evidence used to interpret the past. These data are classified into primary sources and secondary sources. Table 1 shows the classification of primary and secondary sources used to collect the data or information. 
Table 1 Classification of primary and secondary sources used

\begin{tabular}{|l|l|l|}
\hline No & Sources & Explanation \\
\hline $\begin{array}{l}\text { Primary sources: } \\
\text { Original documents, author is a direct witness of the historical event }\end{array}$ \\
\hline 1 & Official documents & $\begin{array}{l}\text { River Document (surat sungai) - River, names of the } \\
\text { Kangchu (Trocki, 1975), and year of the grants }\end{array}$ \\
\cline { 3 - 4 } & $\begin{array}{l}\text { Law of Kangchus (Kanun Kangchu) 1873 - rules } \\
\text { which further explain the position and role of } \\
\text { Kangchu (Coope, 1936) }\end{array}$ \\
\hline $\begin{array}{l}\text { Secondary sources: } \\
\text { Created using primary document, works by other authors writing about history, do } \\
\text { not bear a direct physical relationship to the event }\end{array}$ \\
\hline 1 & Journals / Books & History of kangkar settlements. \\
\hline 2 & Interview & $\begin{array}{l}\text { Scholars or experts who have been collecting and } \\
\text { interpreting local history of kangkar settlements. }\end{array}$ \\
\hline
\end{tabular}

c) Evaluation of historical sources

The historical sources shall be evaluated by external criticism and internal criticism to attest their worth for the purposes of the study. External criticism also known as lower criticism of data, discusses the authenticity of the data whether the document or records that is studying is genuinely valid primary data.

River Document and Law of Kangchus are stored in the Johor Archives, which is the official department by the government that collects and preserves all archives records from Johor. The archival collection of Kangchu system are kept in two registers known as Buku Daftar Surat-surat Keterangan Berkebun 1844-1902 (SKMK-I) and Buku Daftar Surat-surat Keterangan Membuka Kebun Gambir dan Lada Hitam Johor 18801908 (SKMK-II), both generally means "Register of Authorizations for Opening Pepper and Gambier Plantation" (Trocki, 1975).

Secondly, secondary sources which comprising of journals and books produced by scholars such as Carl A. Trocki, A. E. Coope, and the like contributed significantly in identifying the formation of kangkar settlement. They had referred closely to Johor Archives in collecting data and analysis purpose. Trocki is an American historian and an expert in Southeast Asia and China, who discussed the operation of Kangchu system (Klimburg, 2001); Coope is also a scholar experts in the history of
Southeast Asia, who helped to translate Letter of Kangchu Authority (surat tauliah) - the only sample to be referred as no copies found in Johor Archives (Trocki, 1975); whereas Onn Huan Jann compiled a report recorded a field work visited to all traceable kangkar settlements from 2001 to 2002, updated the recent development of kangkar settlements after Trocki.

Internal criticism which is known as upper criticism of data, examines the accuracy of the data in the document. It was noticed that there are a few of the earlier River Documents missing from SKMK-I and II. The information of SKMK also can be checked by comparing SSD (Singapore and Straits Directory) which has a list of Kangchu and river given (Trocki, 1975). The historical data collected from journals and books are strictly contrasted and referred from Johor Archives.

d) Analysing and summarizing data

Interconnecting and complementing the data to answer the questions raised in step a). The data is interconnected based on topics. There are basically two types of content analysis which are influenced by content quality or relational quality. The former examines how often a concept or specific word being mentioned, mostly applied to quantitative research. The later is implemented to explore the relationship between the concepts and keywords, the 
qualitative findings serve for understanding the formation of kangkar settlements (Spilackova, 2012).

The last stage of historical research is validation. Triangulation method is suggested to verify the research conclusions deduced from multiple data obtained by different methods (Mertens \& HesseBiber, 2012). Comparison of archival study, literature review, as well as well interviews of scholars to confront the research findings would help to verify the research conclusion.

\section{Findings and Discussions}

The Chinese agriculturalists of pepper and gambier cultivation set an important departure from the traditional economic systems at Johor Sultanate (Trocki, 1976). In the past, Johor Sultanate comprised Pahang, Johor mainland, Singapore and Riau-Lingga Islands. The establishment of pepper and gambier cultivation initiated from Riau in about 1730. It was then shifted massively to Singapore in 1819 which constituted one of the most basic elements of the Singapore economy. Until 1844 when the first River Document issued to Skudai of Johor, it marks the introduction of Kangchu system and vast opening of Johor in the region.

Kangchu system had developed large part of virgin jungle (Trocki, 1976) into town and cultivated land in Johor. The relationship between Kangchu system, surat sungai, and kangkar are illustrated through Figure 1 which was further explained through findings below.

\subsection{Kangchu System}

The Kangchu system was implemented by the Johor ruler Temenggung Daeng Ibrahim (Trocki, 1976) in inviting the Chinese to develop Johor. It witnessed the vast hectares of virgin land being opened up in Johor (Coope, 1936), (Jackson, 1968; Pek, 2015). A later Chinese observer described it as "an entirely unique and perhaps efficacious system of land-tenure co-operative cultivation” (Jackson, 1968). Kangchu (lit. lord of the river) was the name given to the Chinese headman of kangkar. They were the head of the cultivation, the government's administrator of the area, and held franchise on the revenue monopolies over pawnbroking, gambling, prostitution and the sale of opium, spirits, and pork (Coope, 1936).

In the earlier implementation of Kangchu system, the share of Kangchu was relatively clear. When pepper and gambier business was getting bigger, there was joint venture between individuals and formed a company called Kongsi. However, Kangchu was still the one who managed and stayed in the kangkar settlements (Pek, 2015).

\subsection{Surat Sungai or River Document}

Each Kangchu would have a surat sungai or River Document, basically an economic document which comprised of a collection of contracts, or licenses (Tachimoto, 1994). This authorized them to open pepper and gambier plantations within the watershed of a given river, stream or tributary (Trocki, 1976). Trocki also opined that surat sungai offered a unique glimpse of the earliest efforts by Malay rulers to organize a modern state.

The standard form of surat sungai evolved accordingly, while Trocki categorized them into three different periods. In the preliminary stage, surat sungai was found relatively brief which comprised of date of the grant, name of the tributary, and the name of Kangchu. When the English-educated Sultan Abu Bakar became the ruler of Johor, he began to systematize the administration with the help of European lawyers. Compared to the earlier stage with irregular of information, this period of surat sungai recorded full name of Kangchu, share distribution, and signature of the Kangchu. The final stage was in 1880 when the surat sungai was printed instead of handwritten. The surat sungai appeared to follow the typical model of $19^{\text {th }}$ century English contracts (Trocki, 1975). 


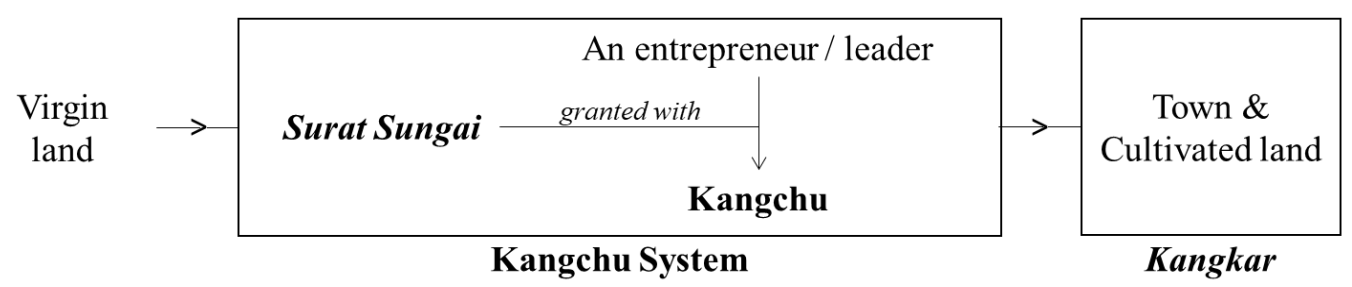

Figure 1 Kangchu System had developed many parts of virgin land in Johor

There is no statement of the size of land granted to Kangchu written in surat sungai other than the information that it was limited to a given watershed. There is also no population or productivity of kangkar settlements could be identified from surat sungai. However the location provides us a clue to locate where the kangkar settlement is, the descendant of Kangchu to be interviewed, and the year of opening the kangkar settlement. Historical data gained from surat sungai and its possible usage for further research was summarized in Table 2 below:

Table 2 Historical data gained from surat sungai

\begin{tabular}{|l|l|l|}
\hline No & Information & Usage \\
\hline 1 & Date of the grant issued & Year the kangkar being opened \\
\hline 2 & Name of Kangchu & $\begin{array}{l}\text { Descendant of Kangchu as interview } \\
\text { candidates }\end{array}$ \\
\hline 3 & Location of plantations & Location of kangkar \\
\hline
\end{tabular}

\subsection{Kangkar Settlements}

Kangkar means the foot of the river in the Teochew dialect (Coope, 1936; Jackson, 1968). It was the riverine settlement for the Chinese immigrants of pepper and gambier plantation cluster (Begbie, 1834). Besides the characteristic of gambier which requires to be at riverside, river also acts as the main transportation to export gambier and pepper.

Each kangkar was governed by a semi-feudal Kangchu (Jackson, 1968). The Chinese settlers were expected to work within the area granted as stated in surat sungai, not to interfere with any property, land, cultivation, or village that already occupied by Malays (Coope, 1936). This could be one of the factors that Chinese and Malay live harmoniously in Johor (Lim, 2009).
A typical kangkar settlements comprised of a village, cultivated land and virgin jungle recognized by the Malay authorities as granted to Kangchu in surat sungai. The size of each kangkar varied in size, ranged from 2,500 acres to 20,000 acres of land. The town of kangkar which was the administrative centre for all the upriver and interior settlements (Trocki, 1976), would made up of a Big House (Coope, 1936), pawnshop, opium, gambling, and prostitution concessions (Pek, 2015). According to (Coope, 1936), the Big House known as "Tua Chu" refers to the Kangchu's House where two canes and a spear kept and given by the Johor ruler. It served as a local court, comprised of a prison inside the house as well as dormitory that could accommodate nearly 100 people (Song, 2015). Pek (2015) had drafted a sample of typical kangkar settlement pattern as in Figure 2. 


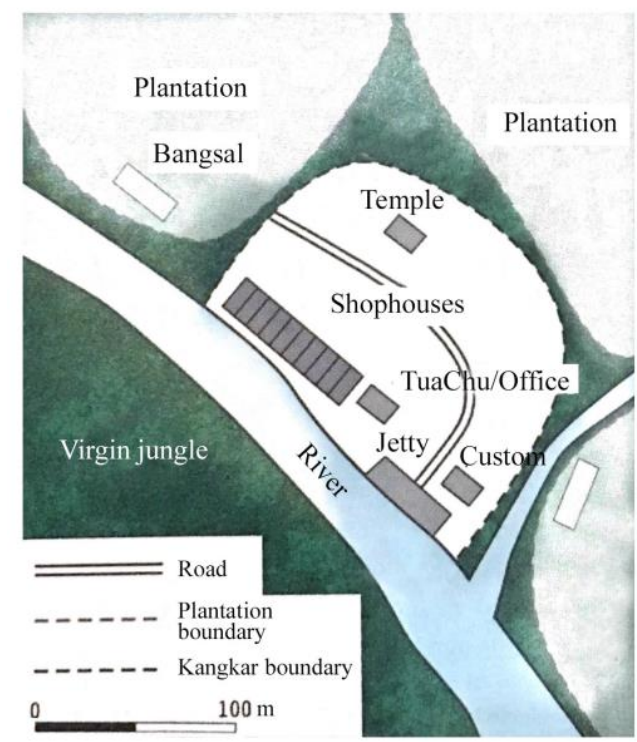

Figure 2 Typical kangkar settlement pattern proposed by Pek (2015)

The first surat sungai issued to Skudai was in 1844 , however the exact location could not be retrieved due to vast development and no historical documentation recorded (Kolej Selatan, 2004). The second surat sungai was issued to Kapitan Tan Kee Soon for Tan Chu Kang, today's Kangkar Tebrau (Wu, 2017). During a visit by Trocki in 1970s to Kangkar Tebrau, he gave the insight of kangkar settlement at that time. Kangkar Tebrau consisted of 3 rows of Chinese shophouses with approximately 50 shophouses. There was a small Chinese temple on the river bank. In 1870, besides opium, gambling, and prostitution concessions like other kangkar settlements, there was market, police station, and a customs office (Trocki, 1976). Today, we still can see the 3 rows of Chinese shophouses and renovated temple. However, many shophouses are left vacant and the settlement is declining.

The Tebrau settlement pre-dated the founding of the Johor's capital at Tanjung Puteri by more than a decade. Trocki opined that Kangkar Tebrau seems to been the local government centre of Johor from 1844 to 1855. The successful of Kangkar Tebrau initiated the development of Johor Bahru, formerly known as Tanjung Puteri. The name of Johor Bahru means "New Mountain", defines Johor Bahru as a newly developed place (Trocki, 1976).

\subsection{Frontier to Modern Johor Economic Development}

It was noticed that most of the Chinese settlements in Johor today were originated from kangkar settlements. They transformed and undergone few changes due to Japanese occupation, Brigg's plan, urbanization, modernization, and the like. In the past, the settlements were flourished due to gambier and pepper cultivation. For those which survive adapted to the needs by changing the commercial planting to rubber in the 1900 s as well as pineapple and oil palm in 1960s. Till date, Malaysia is the world's second largest palm oil producer after Indonesia while Johor is the top in Peninsular Malaysia (Department of Statisctics, 2017). This marks the importance of Chinese as the frontier to modern Johor economic development.

\section{Conclusion}

Kangkar as the frontier of Chinese settlement which existed due to Kangchu system that only occurred in Johor, is significant to Chinese agricultural settlement and architectural paradigm. Being the earliest established Chinese settlement in Johor, the morphology or architectural aspects are believed worth to be studied in the following research. It could possibly able to reveal how the mainland Chinese adapted to the local context, later formed a 
unique Chinese settlement that is kangkar. Besides, comparative study could be carried out with other Chinese settlements in Johor, for instance New Villages since 1950 s and modern housing in the $20^{\text {th }}$ century to search for the changes of Johor Chinese settlements.

Undeniably, kangkar plays important and positive roles in Johor development in terms of economy, coexistence, and identity. However, there are still lack of sufficient study on this unique settlement which could led to the loss of humanity's heritage as well as diversity. Besides adding more literature contribution, it is also crucial to preserve the kangkar settlements for instances by providing insight of guideline to sustain and avoid further its further decline.

\section{Acknowledgement}

The authors would like to express their appreciation for the financial support of the sponsor Universiti Teknologi Malaysia (UTM) through GUP Grant Tier 2 with cost center Q.K130000.2609.15J69 and Zamalah Scholarship.

\section{References}

Begbie, P. J. (1834). The Malayan Peninsula. Vepery Mission Press. Madras.

Coope, A. E. (1936). The Kangchu System in Johore. Journal of the Malaysian Branch of the Royal Asiatic Society. 14(3): 247-263.

Cowgill, A. V. (1924). Chinese Place - names in Johore. Malaysian Branch of the Royal Asiatic. 2(3): 221-251.

Filho, A. J. A. (2016). The Historical Research: Theory, Methodology, and Historiography. Historia Da Enfermagen. 7(2): 381-382.

Jackson, J. C. (1968). Planters and Speculators: Chinese and European Agricultural Enterprise in Malaya, 1786-1921. Kuala Lumpur: University of Malaya Press.

Klimburg, A. (2001). Some Research Notes on Carl A. Trocki's Publication "Opium, Empire and the Global Political Economy." Bulletin of the School of Oriental and African Studies. 64(2): 260 267.

Kolej Selatan. (2004). The Formation \& Development of Teow Chew in Johor 柔佛州潮人拓殖与发展史稿 (1st ed.). Masai: Southern College Press.

Lim, P. P. H. (2009). Johor 1855 - 1957 Local History, Local Landscapes. Singapore: Straits Times Press.
Loh, P. (2017). My Johor Stories. Petaling Jaya: MPH Group Publishing Sdn Bhd.

Mertens, D. M., \& Hesse-Biber, S. (2012). Triangulation and Mixed Methods Research: Provocative Positions. Journal of Mixed Methods Research. 6(2): 75-79.

Onn, H. J., Wu, W., \& Su, K. S. (2013). The Historical Collection of Johor Ngee Heng 柔佛义兴史料集. Johor Bahru: Johor Bahru Chinese Heritage Museum.

Ooi, K. G. (2009). Historical Dictionary of Malaysia. London: Scarecrow Press.

Pek, W. C. (2015). Transformation of the Chinese Society in Johor Bahru, Johor, 1855-1942 柔佛新山华人社会的变迁与整合: 1855-1942 (1st ed.). Johor Bahru: New Era College.

Spilackova, M. (2012). Historical Research in Social Work Theory and Practice. ERIS Web Journal. 3(2): 22-33.

Tachimoto, N. M. (1994). Coping with the Currents of Change: A Frontier Bugis Settlement in Johor, Malaysia. Southeast Asian Studies. 32(2): 197-230.

Trocki, C. A. (1975). Johor Archives \& Kangchu System $1844-$ 1910: A Bibliographic Essay. Malaysian Branch of the Royal Asiatic, 48(Part 1).

Trocki, C. A. (1976). The Origins of the Kangchu System 17401860. Journal of the Malaysian Branch of the Royal Asiatic Society. 49(2): 132-155.

Wu, W. (2017). The Selected Works of Wu Wah. (H. J. Onn, Ed.). Masai: Southern University College.

Wyche, S., Sengers, P., \& Grinter, R. E. (2006). Historical Analysis: Using the Past to Design the Future. In A. Dourish, Paul; Friday (Ed.), UbiComp 2006: Ubiquitous Computing (Vol. 4206, pp. 33-51). Orange County: Springer.

Yoji, A., \& Mako, Y. (2008). New Perspectives on the Japanese Occupation of Malaya and Singapore, 1941-45. Singapore: NUS Press.

Department of Statisctics. (2017). Percentage Share of Agriculture Sector by State, 2016. Retrieved February 27, 2018 , from https: / / www.dosm.gov.my/v1/index.php?r=column/ctheme ByCat\&cat=102\&bul_id=VS9Gckp1UUpKQUFWS1JHUnJZS2 xzdz09\&menu_id=TE5CRUZCblh4ZTZMODZIbmk2aWRRQ T09

Song, P. J. (2015). The Big House in Grisek. Retrieved February 26, 2018, from http: / / www.mysinchew.com/node/106277/tid=13 